\title{
The PALMer LTER: A LONG-Term ECOLOGICAL RESEARCH PROGRAM at PALMER Station, AnTARctica
}

\author{
By Raymond C. Smith, Karen S. Baker, \\ William R. Fraser, Eileen E. Hofmann, \\ David M. Karl, John M. Klinck, \\ Langdon B. Quetin, Barbara B. Prézelin, \\ Robin M. Ross, Wayne Z. Trivelpiece \\ and Maria Vernet
}

$\mathrm{T}$ HE ANTARCTIC marine ecosystem-the assemblage of plants, animals, ocean, sea ice, and island components south of the Antarctic Convergenceis among the largest readily defined ecosystems on Earth $\left(36 \times 10^{6} \mathrm{~km}^{2}\right)$ (Hedgpeth, 1977; Petit et al., 1991). This ecosystem is composed of an interconnected system of functionally distinct hydrographic and biogeochemical subdivisions (Treguer and Jacques, 1992) and includes open ocean, frontal regions, shelf-slope waters, sea ice, and marginal ice zones. Oceanic, atmospheric, and biogeochemical processes within this system are thought to be globally significant, have been infrequently studied, and are poorly understood relative to more accessible marine ecosystems (Harris and Stonehouse, 1991; Johannessen et al., 1994). The Palmer Long-Term Ecological Research (Palmer LTER) area west of the Antarctic Peninsula (Fig. 1a) is a complex combination of a coastal/continental shelf zone and a seasonal sea ice zone, because this area is swept by the yearly advance and retreat of sea ice. The Palmer LTER program is a

R.C. Smith (bio-optics, remote sensing), University of California, Santa Barbara, Institute for Computational Earth System Science (ICESS), Geography Department, Santa Barbara, CA 93106. USA; K.S. Baker (data management), M. Vernet (primary production), University of California, San Diego, Scripps Institution of Oceanography, Marine Research Division, La Jolla. CA 92093-0218. USA: W.R. Fraser (apex predators), W.Z. Trivelpiece (apex predators), Montana State University, Polar Oceans Research Group. Department of Biology, 310 Lewis Hall, Bozeman, Montana 59717, USA; E.E. Hofmann (biophysical modeling), J.M. Klinck (physical ocean modeling), Old Dominion University. Center for Coastal Physical Oceanography, 768 West - 52nd Street, Norfolk. VA 23529-2076. USA; D.M. Karl (microbial ecology). University of Hawaii at Manoa, Department of Oceanography, 1000 Pope Road, Honolulu, Hawaii 96822, USA; L.B. Quetin (secondary producers), R.M. Ross (secondary producers), B.B. Prézelin (primary production), University of California, Santa Barbara, Marine Science Institute, Santa Barbara, CA 93106, USA. multidisciplinary program established to study this polar marine ecosystem.

Long-term ecological research addresses the temporal gap between short-term process-oriented studies and paleo-oceanography by studying processes on time scales from months to decades to centuries. Such studies provide opportunities for contemporaneous hypothesis testing across interrelated phenomena, where cause and effect can only be detected on longer time scales. For example, there is now widespread recognition that there are numerous natural and anthropogenically forced phenomena, such as atmospheric ozone depletion, green-house gas accumulations, El Niño-Southern Oscillation (ENSO), global deforestation and sun spot cycles, with potentially significant ecological impacts that will require long-term studies to resolve. Further, long-term research has been shown to be especially important in the study of a variety of ecological phenomena like the following (Strayer et al., 1986): 1) slow processes, such as long life cycles of key species, 2) episodic phenomena, such as relatively rare and intense physical forcing, 3) processes with high levels of yearto-year variability, such as climate in polar regions, and 4) elusive and/or complex processes where it is difficult to distinguish meaningful patterns from random events, such as interannual variability of recruitment success of keystone species.

The National Science Foundation (NSF) created the Long-Term Ecological Research (LTER) Network in 1981 by establishing six sites in the continental United States (Brenneman, 1989). From its inception, the LTER program has endeavored to coordinate research from each site for possible intersite and transdisciplinary interpretation of longterm ecological phenomena (Franklin et al., 1990). The LTER Network supports a comprehensive set of core measurements across the sites, in addition

\author{
The Palmer LTER \\ program is a \\ multidisciplinary
}

program established to

study this polar marine

ecosystem. 

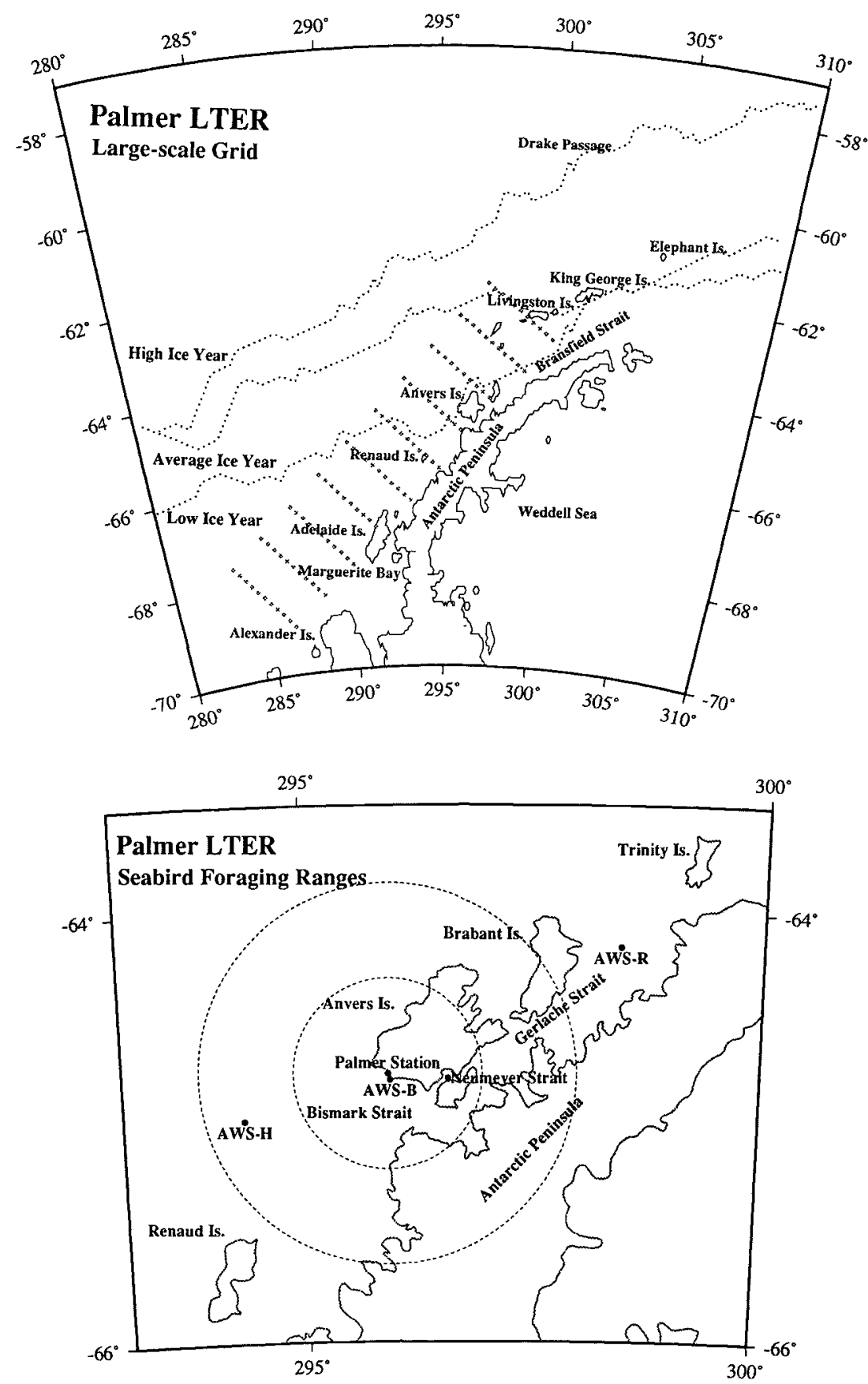

Fig. 1: (a) The Palmer LTER region located west of the Antarctica Peninsula, Antarctica. Points show the location of cardinal sampling stations within the large-scale peninsula grid which covers an area of $900 \mathrm{~km}$ (roughly parallel to the peninsula) by $200 \mathrm{~km}$ (on to off-shore). Sea ice extent for low, average, and high ice years is indicated by fine dotted lines and corresponds to the color plate shown on the back cover. (b) The Palmer Basin area. Palmer Station is located at the southern end of Anvers Island. The foraging ranges of the seabirds during the reproductive season are indicated by the concentric circles at 50 and $100 \mathrm{~km}$ from Palmer Station. A fine-scale sampling grid exists within $\sim 3 \mathrm{~km}$ of Palmer Station. Automatic Weather Station (AWS) installations within the area are labeled $A W S$ where $B=$ Bonaparte, $H=H u g o$, and $R=$ Racer Rock. to project-specific field experiments designed to test site-specific hypotheses (Callahan, 1984). The set of core measurements include: primary production, nutrient concentrations and cycling rates, organic matter transport, trophic interactions, and effects of natural and anthropogenic disturbances. Currently, the LTER Network includes 18 sites with diverse ecosystems, including Arctic tundra, hardwood forests, lakes, streams, prairie grasslands, high deserts, tropical rainforests, as well as Antarctic coastal and terrestrial desert regions. The Palmer LTER program was established in 1990, was the first LTER site in the Southern Hemisphere, and is the only marine (from coastal to pelagic) site in the LTER Network. We share with other sites similar core measurements, as well as the unifying ecological concept that physical factors force the biology of the system.

Over the past 15 years there have been several major multiyear studies of the Antarctic marine ecosystem. Although many studies were conducted mostly north and east of the Antarctic Peninsula, there were three BIOMASS (Biological Investigations of Marine Antarctic Systems and Stocks) research cruises which were carried out in the southwest Atlantic Ocean, including the northwest extent of the Palmer LTER study region (El-Sayed, 1994). BIOMASS was an international multidisciplinary program conducted from 1980 to 1985 , which studied and assessed the standing stocks of micro- and macroorganisms in the Antarctic ecosystem, making significant contributions to our understanding of Southern Ocean ecology. AMERIEZ (Antarctic Marine Ecosystem Research on Ice Edge Zones) concentrated on seasonal iceedge dynamics through a series of research cruises from 1983 to 1986 in the Weddell Sea (Ainley et al., 1986). The RACER (Research on Antarctic Coastal Ecosystem Rates) program conducted a comprehensive summer study of coastal processes in the western Bransfield Strait (1986-87) and in the Gerlache Strait (1989) (Karl, 1991), and in subsequent years revisited the study area and expanded their temporal (austral winter) and spatial [Grandidier Channel, Crystal Sound and Marguerite Bay which are in the present LTER area (Fig. 1)] coverage. The AMLR (Antarctic Marine Living Resources) program, sponsored by the National Oceanic and Atmospheric Administration (NOAA), maintains an annual ecosystem study which focuses on trophic linkages in the vicinity of Elephant Island, an area northwest of the Palmer LTER study region. AMLR also supports some seabird work in the Palmer LTER study region. Recently, as part of the Southern Ocean Joint Global Ocean Flux Study (JGOFS), the U.K. "Sterna" study was carried out in the southeast Pacific sector of the Bellingshausen Sea (Turner and Owens, 1995). This program evaluated the magnitude and variability of biogeochemical fluxes and investigated primary production in different 
environments and communities of direct relevance to the Palmer LTER such as: 1) the microbial communities growing in or on the ice, 2) the marginal ice zone (MIZ) determined by the persistence of meltwater density structure, and 3) the open-water pelagic areas. All of these studies made significant contributions to our overall understanding of the Antarctic marine ecosystem and the early ones were instrumental in the design of the Palmer LTER program.

A central tenet of the Palmer LTER is that the annual advance and retreat of sea ice is a major physical determinant of spatial and temporal changes in the structure and function of the Antarctic marine ecosystem, from total annual primary production to breeding success in seabirds. We are working with a number of testable hypotheses linking sea ice to 1) the timing and magnitude of seasonal primary production, 2) the dynamics of the microbial loop and particle sedimentation, 3) krill abundance, distribution, and recruitment, and 4) the survivorship and reproductive success of apex predators. The overall objectives of the Palmer LTER are to 1) document the interannual variability of annual sea ice and the corresponding physics, chemistry, optics, and primary production within the study area, as well as the life-history parameters of secondary producers and apex predators, 2) identify the processes that cause variation in physical forcing and the subsequent biological response among the representative trophic levels, 3) construct models that link ecosystem processes to environmental variables and that simulate spatial/temporal ecosystem relationships, and 4) employ such models to predict and validate ice-ecosystem dynamics. A key challenge for the Palmer LTER project is to characterize and understand the linkages between the different spatial and temporal scales of the various physical and biological components of the Antarctic ecosystem.

To structure our long-term regional observations, we created a sampling grid along the west coast of the Antarctic Peninsula (Waters and Smith, 1992), analogous to the well-known CalCOFI (California Cooperative Oceanic Fisheries Investigations) grid along the west coast of North America. Establishing a fixed sampling grid was motivated by the need for station locations that could be visited repeatedly over time scales of many years. This geographically fixed study area will also simplify seasonal and interannual comparisons and facilitate modeling of multidisciplinary data sets. We have embedded within the large-scale peninsula grid smaller sampling grids in the vicinity of Palmer Station (Fig. 1b) to focus on the foraging ranges of our apex predators (roughly $100 \mathrm{~km}$ from Palmer Station). In addition, we have a fine-scale grid in the immediate vicinity of Palmer Station (within the $3.7 \mathrm{~km}$ boating limit), which is specific to the local hydrogra- phy, primary and secondary production and sea bird nesting sites. Sea ice, in situ bio-optical water properties, temperature, conductivity, dissolved $\mathrm{CO}_{2}$ concentrations and estimated air-sea fluxes, photosynthetic pigments, nutrient concentrations, phytoplankton and bacterioplankton abundance and production rates, zooplankton abundance and composition, secondary production, particle sedimentation and seabird ecology are routinely sampled and/or monitored within the grids.

\section{The Antarctic Marine Ecosystem}

As noted by many previous studies, a dominant and distinguishing characteristic of Southern Ocean marine ecology is sea ice. Hunt (1991) and Ainley et al. (1994) discuss the influence of varying sea ice coverage on seabird environments and trophic level coupling. According to these studies, different springtime seabird habitats associated with varying sea ice coverage, which therefore have different implications on trophic level coupling, are the following: 1) open leads and polynyas, through which seabirds can gain access to the water column and underside of sea ice, 2) the ice edge, which can either be compact or highly diffuse, and which is a major ecological boundary, and 3) the outer marginal ice zone (MIZ), where meltwater contributes to stabilization of the water column. The MIZ is an area bounded on the open ocean side by the stabilizing influence of meltwater and on the pack ice side by the penetration of ocean swell (Stammerjohn and Smith, 1995). The MIZ can be up to $250 \mathrm{~km}$ in width and is often an area of high biological productivity (Smith and Nelson, 1985). It is also an ecosystem boundary where the flow of energy, the cycling of nutrients and the structure of biological communities change dramatically, both temporally and spatially. The areal extent of sea ice cover and the associated timing of the MIZ in relation to specific geographic areas (e.g., seabird rookeries) have high interannual variability. The range for variable ice cover is shown schematically in Fig. la. Sea ice extent for low, average, and high ice years are indicated (Stammerjohn and Smith, 1996).

Mesoscale oceanic circulation patterns in the large-scale LTER grid are not well known (Hofmann et al., 1996). The barotropic circulation is unknown, and there are no direct current measurements anywhere in the region. Even tidal characteristics are poorly known (Amos, 1993). There are some suggestions of the direction of flow on the shelf from dynamic calculations and other indirect indications. The Antarctic Circumpolar Current (ACC) stands out in all calculations and flows northeasterly off the shelf. There are a number of indications of southward flow on the inner part of the shelf (Fig. 2). Some studies suggest the existence of two gyres (Stein, 1992), but it is not certain whether permanent eddies are part of the
. . the annual

advance and retreat of

sea ice is a major

physical determinant

of spatial and temporal

changes in the

structure and function

of the Antarctic marine

ecosystem . . . 


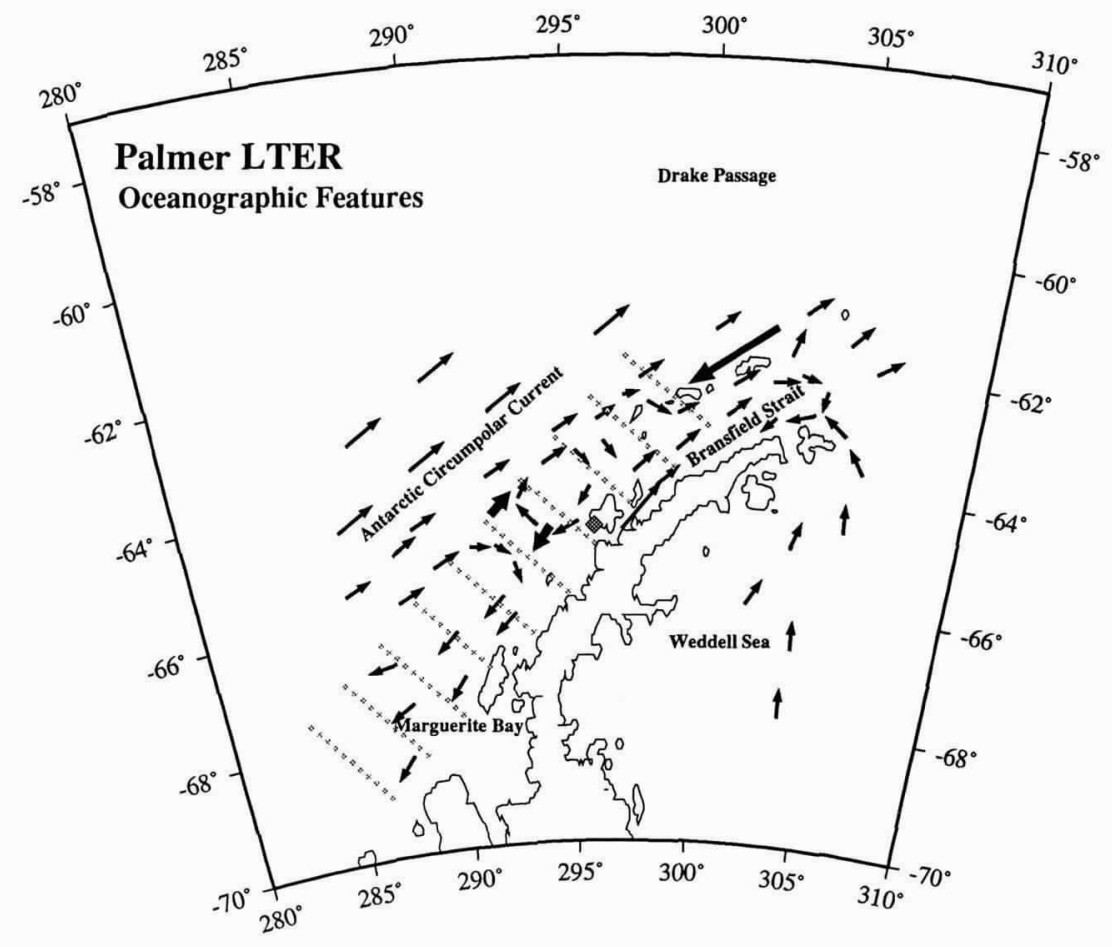

Fig. 2: Schematic showing the circulation in the upper 200-300 $\mathrm{m}$ to the west of the Antarctic Peninsula. The Polar Slope Current is indicated by the long arrow north of Bransfield Strait, and the two smaller wide arrows in the Bellingshausen Sea represent the possibility of a single cyclonic gyre in this region. The Palmer LTER large-scale peninsula grid is shown by fine dots.

coastal circulation, or if the coastal flow is merely convoluted and not sampled sufficiently to resolve its features. The most prominent water mass west of the Antarctic Peninsula is Circumpolar Deep Water (CDW), which is characterized by temperatures greater than $0.5^{\circ} \mathrm{C}$ and by salinities of 34.75 (Hofmann et al., 1996). The CDW brings macronutrients onto the shelf, as well as warm salty water. The presence of a warm, salty water mass near the bottom of the mixed layer has considerable implications for heat and salt budgets in this region. In addition, the circulation patterns and the presence of CDW may affect the timing and extent of sea ice, as well as the transport and/or retention of physical and biological properties in the Palmer LTER area.

Smith et al. (1996b) have recently reviewed historical phytoplankton biomass and productivity data for the Palmer LTER region and conclude that the average productivity of the region is on the order of a few hundred grams $\mathrm{C} \mathrm{m}^{-2} \mathrm{y}^{-1}$ which is roughly about a factor of 5 lower than other productive coastal areas of the world's oceans (Chavez and Barber, 1987). Factors that regulate primary production within this environment include those that control cell growth (light, temperature, and nutrients) and those that control the accumulation rate of cells and hence population growth (water column stability, grazing, sinking, and advection). Sea ice mediates several of these factors and often, but not always, conditions the water column for an initial bloom which is characterized by a pulse of production restricted in both space and time. The relationship of the relative contribution of bloom versus nonbloom primary productivity to the timing and balance of the resulting food web dynamics is currently unknown.

Like most marine food webs studied so far, the trophic relationships in Antarctica are complex. However, the links between primary producers, grazers and apex predators (seabirds, seals, and whales) are often short and may involve fewer than four key species (Fig. 3). Predators tend to concentrate on a core group of prey species, for example, the abundant euphausiids and fish close to the base of the food web. The general sampling approach in our study capitalizes on the close coupling between trophic levels, the limited number of species involved, and the fact that the dominant predators are seabirds that nest on land and are thus easily accessible during the spring and summer breeding season. The two key apex predators we study are the Adélie penguins (Pygoscelis adeliae), which dominate the seabird assemblage near Palmer Station in terms of abundance and biomass, and the south polar skuas (Catharacta maccormicki), which inhabit numerous small islands in the vicinity of Palmer Station. During the summer breeding season, these seabirds depend on resources that can be found within their respective

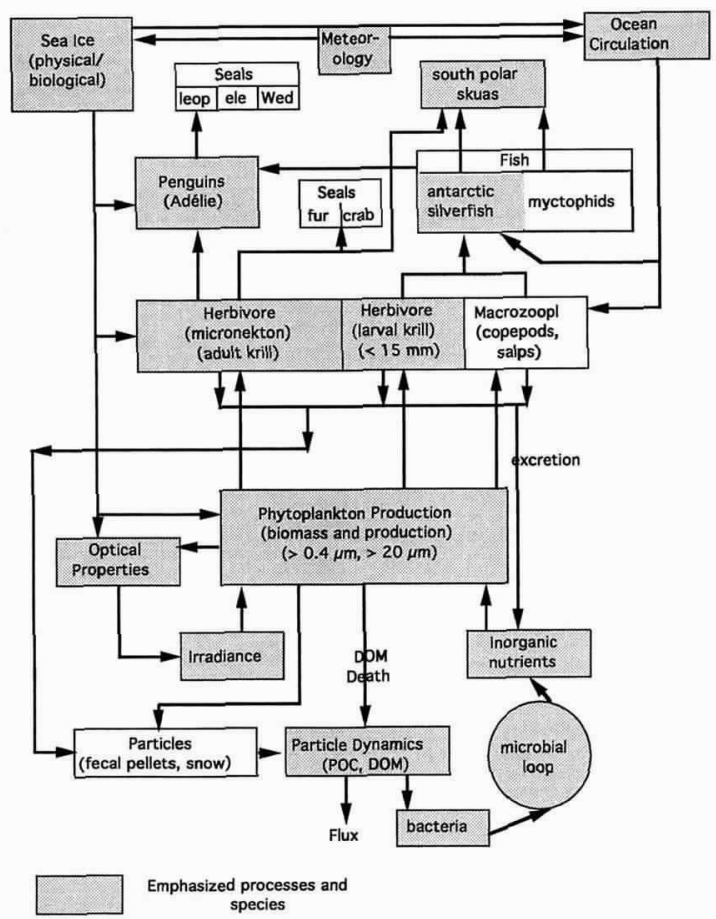

Fig. 3: Conceptual diagram of the ecosystem (food web and environmental factors) investigated by the Palmer LTER. Boxes indicate various key components within this Antarctic marine ecosystem. 
foraging ranges, which are believed to be within $100 \mathrm{~km}$ of the breeding sites. Finding sufficient prey within these foraging ranges is critical to the reproductive success of these birds. Preferred prey for Adélie penguins is Antarctic krill (Euphausia superba) and for south polar skuas, silverfish (Pleuragramma antarcticum). Both prey are found within the various marine habitats inside these foraging ranges, but the timing of prey availability and abundance is highly variable from year to year. Potential mechanisms controlling prey availability within the foraging ranges may include 1) changes in water mass distribution and oceanic currents (meanders and eddies), 2) variability in reproductive and recruitment success of the prey, 3 ) patchiness, abundance and type of prey food, and 4) prey behavior and predation.

\section{Conceptual Model of Physical and Biological Linkages}

Solar radiation, atmospheric and oceanic circulation as well as sea ice cover are the physical forcing mechanisms driving variability in biological processes at all trophic levels in Antarctica. Analyzing the extreme seasonality of these forcing mechanisms in conjunction with the seasonal timing of ecologically important events and life histories of key species from each trophic level provides a conceptual model for the discussion of trophic linkages (Fig. 4). Some of the components in Figure 4 are known with relative certainty, while others are proposed based on our current knowledge and hypotheses.

Weather in the Palmer LTER study area is extremely variable, both seasonally and interannually. Solar radiation has a strong seasonal cycle at these latitudes, with shortwave $(0.3$ to $3.0 \mu \mathrm{m})$ input varying from close to zero in winter to 390 $\mathrm{W} \mathrm{\textrm {m } ^ { - 2 }}$ under cloud-free conditions near summer solstice. Daylength, a key biological parameter, varies from 9 hours in early spring to more than 20 hours in midsummer. It also has different regulating effects on phytoplankton growth, as does total photosynthetically available radiation (PAR), another key parameter. Anthropogenic ozone-related increases in ultraviolet $B$ (UVB) radiation $(280-320 \mathrm{~nm})$ are well documented, and spring and early summer UVB values are dramatically higher today than they were under preozone hole conditions (Smith et al., 1992). Cloud cover is persistent and strongly influences the heat budget, incident PAR and ultraviolet radiation. In general, weather in the Palmer LTER study area is typically maritime Antarctic, with snow $\left(70 \mathrm{~cm} \mathrm{y}^{-1}\right)$ and rain $\left(40 \mathrm{~cm} \mathrm{y}^{-1}\right)$ occurring any time of the year. Temperatures at Palmer Station are relatively mild, averaging about $-6^{\circ} \mathrm{C}$ in July and $3^{\circ} \mathrm{C}$ in January, with temperature extremes recorded at $-25^{\circ} \mathrm{C}$ and $10^{\circ} \mathrm{C}$. Weather, while mild by comparison to the interior of the Antarctic, has a strong annual cycle, is punctuated by episodic storm events, and shows an interannual variability in continental influence, especially during winter (Smith et al., 1996a). Automatic weather station (AWS) units (Bromwich and Stearns, 1993) have now been installed at the end of Bonaparte Point $\left(64^{\circ} 46^{\prime} \mathrm{S}, 64^{\circ} 04^{\prime} \mathrm{W}\right)$ near Palmer Station and in the Hugo archipelago $\left(64^{\circ} 57^{\prime} \mathrm{S}, 65^{\circ} 41^{\prime} \mathrm{W}\right)$. These together with the AWS on Racer Rock $\left(64^{\circ} 10^{\prime} \mathrm{S}\right.$, $61^{\circ} 32^{\prime} \mathrm{W}$ ) in the Gerlache Strait, make a suite of three AWS installations within the Palmer LTER study area, in addition to the Palmer Station weather records (Baker and Stammerjohn, 1995).

The timing and extent of the annual advance and retreat of sea ice in the vicinity of Palmer Station are highly variable. Analysis of satellite passive microwave data, available from the past 17 years, shows that the Palmer LTER study area has a mean annual ice cycle that, in contrast to mean annual cycles of other areas of the Southern Ocean, typically involves a relatively short period of ice advance $(5 \mathrm{mo})$, followed by a relatively long period of ice retreat $(7 \mathrm{mo}$ ) (Stammerjohn, 1993; Stammerjohn and Smith, 1996). In addition, the satellite data show some evidence of a recurrent 6 to 8 year cycle, where several consecutive high ice years (1979-82, 1986-87, and 1991-92) alternate with consecutive low ice years (1983-85, 1988-90, and 1993-94). This time series is still too short to resolve any persistent low frequency periods statistically, but evidence is accumulating to show that high interannual variability in magnitude, timing of ice advance and retreat, duration of near maximum and minimum ice coverage, and apparent clumping of high or low ice years have a significant impact on the survival rates, distributions and/or life histories of key indicator species (Ross and Quetin, 1991; Fraser et al., 1992; Fraser and Trivelpiece, 1996; Siegel and Loeb, 1995). Further, we are beginning to define the physical forcings (e.g., thermodynamics versus advective processes) controlling variability in sea ice coverage and the resulting ecological consequences.

There are hydrographic seasonal variations of temperature and salinity in the upper 0 to $100-150$ $\mathrm{m}$ of the water column. In winter, temperature and salinity are uniform down to $\sim 100 \mathrm{~m}$ (Hofmann $e t$ al., 1996). Beginning in spring and during summer, the ocean warms from the surface, creating one or more layers of warmer water that are a few tens of meters thick. Episodic storms mix these layers so that the vertical temperature structure near the surface can be quite variable. There is also some freshening of the surface layer during summer due to sea ice and glacier melt, which can play a key role in stabilizing the water column and hence increase rates of primary production. Depending on the intensity of macrozooplankton grazing, phytoplankton biomass can accumulate near the surface. Although variations in salinity are small, the density and stability of the upper water column are more a function of salinity than
... the seasonal tim-

ing of ecologically im-

portant events and life

histories of key

species from each

trophic level provides

a conceptual model for

the discussion of

trophic linkages . . . 
. . we must view the

microbial loop models

as hypotheses that de-

serve a thorough,

quantitative field eval-

uation. temperature. It appears that the CDW floods the shelf throughout the year, characterizing the deep waters in the LTER study area.

Key factors controlling phytoplankton cell and population growth in waters of the Southern Ocean are 1) extreme seasonal variability in PAR (mediated by daylength and clouds), 2) low temperatures, 3) generally high nutrient levels, and 4) springtime water column stability (mediated by sea ice and glacier melt and surface heating). The relative contribution of MIZ-related production to overall production continues to be debated. Smith and Nelson (1985) and Smith et al. (1987) show evidence that the MIZ, especially in spring, supports high phytoplankton biomass and/or high production rates. On the other hand, recent observations (Lancelot et al., 1993; Boyd et al., 1995) suggest that specific meteorological conditions influence whether blooms do or do not occur in the MIZ. Nonetheless, total annual productivity is thought to be dominated by the high production rates associated with spring blooms, whose development may be timed and paced by ice-driven water column stability and/or favorable meteorological conditions. The timing of this burst of production and consequent food availability for prey and thus predator, as well as the habitat considerations associated with these environmental conditions, affect a variable mix of trophic level interactions (Fig. 4). These couplings are subject not only to the progression of the seasons, but also to episodic events that disrupt and/or reset the cycle of water column stability, phytoplankton productivity, and subsequent linkages.

Our models of the trophic organization of Antarctic marine ecosystems have evolved considerably during the past decade. Prior to 1980 , energy flow in Southern Ocean habitats was thought to be dominated by relatively short and, therefore, efficient transfers from large $(>20 \mu \mathrm{m})$ phytoplankton cells to krill and, subsequently, to apex predators. More recently, our concept of the marine food web has been expanded to reflect the potential roles of heterotrophic microorganisms including bacteria, protozoans and small $(<150 \mu \mathrm{m})$ nonkrill crustaceans. Heterotrophic microorganism-based food webs, also referred to as microbial loops (Azam et al., 1983) are present in all aquatic environments including Antarctic habitats. These detritus-driven systems are fueled by nonrespiratory community carbon losses, including dissolved and particulate organic matter released by excretion, predation, and mortality. Because microbial loops require several trophic levels to transfer carbon and energy to apex predators, most detritusbased food webs are inherently inefficient and sometimes constitute major energy sinks. It is important to emphasize that comprehensive, quantitative ecosystem studies of energy and carbon flow in Antarctic food webs do not exist. At best, there are order of magnitude estimates for a few se- lected regions. A major, unexpected result of the Antarctic field studies conducted so far is the apparent short-term uncoupling of algal and bacterial metabolic processes (Cota et al., 1990; Karl et al., 1991; Karl and Bird, 1993). The reasons for this uncoupling are not well understood. Consequently, we must view the microbial loop models as hypotheses that deserve a thorough, quantitative field evaluation.

Sea ice provides one of the major habitats for microorganisms in Antarctic marine ecosystems, and it is possible that some microbial food webs may be entirely ice-associated (Palmisano and Garrison, 1993). In the Palmer LTER program, we have just begun to investigate these unique habitats systematically. Preliminary results suggest that the bacterial community goes through several as yet poorly-defined stages of succession as the annual pack ice recedes (Christian and Karl, 1994). The water is initially seeded with bacteria, as well as substantial inputs of organic matter that may be quite different in chemical composition from the organic matter in the water column. Phytoplankton blooms at the receding ice edge provide additional sources of organic matter, through excretion, lysis, and grazing, that are likely to be present only for a short time. Furthermore, photochemical alteration of dissolved organic matter may be accelerated in the sea ice habitat, because it is immobilized in a region of high UV and visible light flux. These processes are likely to play an important role in the adaptation of marine bacteria to this seasonally variable environment, and the biochemical characteristics of the bacteria may change rapidly with time. Future studies will focus on the quantitative role that variations in ice cover may have on the presence and intensity of microbial loop processes.

Associated with the increase in daylength and the melting of sea ice, both contributing to water column stratification, phytoplankton biomass (chla) in the Palmer LTER area starts to accumulate near the end of November in an average ice year. The average chl- $a$ in the top $30 \mathrm{~m}$ can increase from $<0.5 \mathrm{mg} \mathrm{m}^{-3}$ in a pre-bloom period, to higher than $15 \mathrm{mg} \mathrm{m}^{-3}$ during a spring bloom, with average values between 1 and $3 \mathrm{mg} \mathrm{m}^{-3}$ (Smith et al., 1995b). Blooms are mostly dominated by cells $>20 \mu \mathrm{m}$, which are typically large or chain-forming diatoms, although cells $<20 \mu \mathrm{m}$ also grow during a bloom (i.e., cryptomonads and prasinophytes). On occasion, the bloom is dominated by the colonial prymnesiophyte Phaeocystis pouchettii. Smaller diatoms and flagellates dominate during nonbloom periods (Holm-Hansen et al., 1989). In the open ocean a massive sedimentation of phytoplankton often accompanies the termination of the spring bloom. The termination could be caused by cell advection, sinking and/or zooplankton grazing, which leads to the recycling of materials in the euphotic zone and reduces export particle 
flux. Large fluxes of organic matter have been observed in sediment traps, sometimes after a period of intense erosion of the mixed layer, as might occur during a storm. In contrast, the development of a massive coastal bloom, even for a short period of time (days or weeks), can significantly decrease inorganic nutrients which then terminates the bloom. Surface nitrate concentrations in coastal waters of the western Antarctic Peninsula region can decrease from $25 \mu \mathrm{M}$, when nonbloom chl- $a$ concentrations are typically $0.5 \mathrm{mg} \mathrm{m}^{-3}$, to near depleted levels $(<0.1 \mu \mathrm{M})$, when bloom chl$a$ concentrations can be $>35 \mathrm{mg} \mathrm{m}^{-3}$ (Kocmur et al., 1990). The coastal bloom, in terms of continued new/export production, crashes unless nutrients are replenished by mixing and erosion of the mixed layer or by advection of richer offshore waters. However, production can continue without allochthonous nutrients, if nutrients are locally regenerated. During summer chl- $a$ concentrations remain intermediate $\left(1-2 \mathrm{mg} \mathrm{m}^{-3}\right)$ in both open ocean and coastal areas, although periodic blooms may still occur nearshore. Fall blooms may appear in late February and March.

Palmer LTER predator/prey time-lines include the critical periods during reproduction of the two chosen prey/predator pairs (krill/Adélie penguins and silverfish/south polar skuas). All four species are relatively long-lived. Antarctic krill live for 5 to $7 \mathrm{y}$, reproducing as early as their third summer. Ovarian development begins in austral spring, and the rate of ovarian development is dependent on food availability. A prolonged spawning season runs from late December to early March. Both the proportion of the population reproducing and the length of the spawning season are dependent on food availability during spring and summer. Iceedge blooms, occurring prior to open-water blooms, are thought to be one source of food essential to high reproductive output throughout the summer (Quetin et al., 1994). After spawning the embryos sink, hatch at depth, and the early nonfeeding larvae ascend through the water column. The first critical period occurs when early larvae arrive at the surface, about three weeks after release, and need food. Winter is the second critical period, because unlike adults, larvae lack energy stores. The 6-mo long fall and winter period of low food availability in the water column can create starvation conditions for the young-of-the-year (Ross and Quetin, 1991). The essential winter grazing ground for larvae is the under-ice habitat where they feed on ice algae. Thus, larval survival and recruitment are hypothesized to be enhanced by the presence and duration of winter ice. Grazing pressure from the three dominant macrozooplankton groups (krill, salps, and copepods) varies with season. Krill are present all year round in surface layers. Grazing pressure by adults is lower in late fall and winter, although larvae continue to feed on ice algae if sea ice is present. Salps gener-

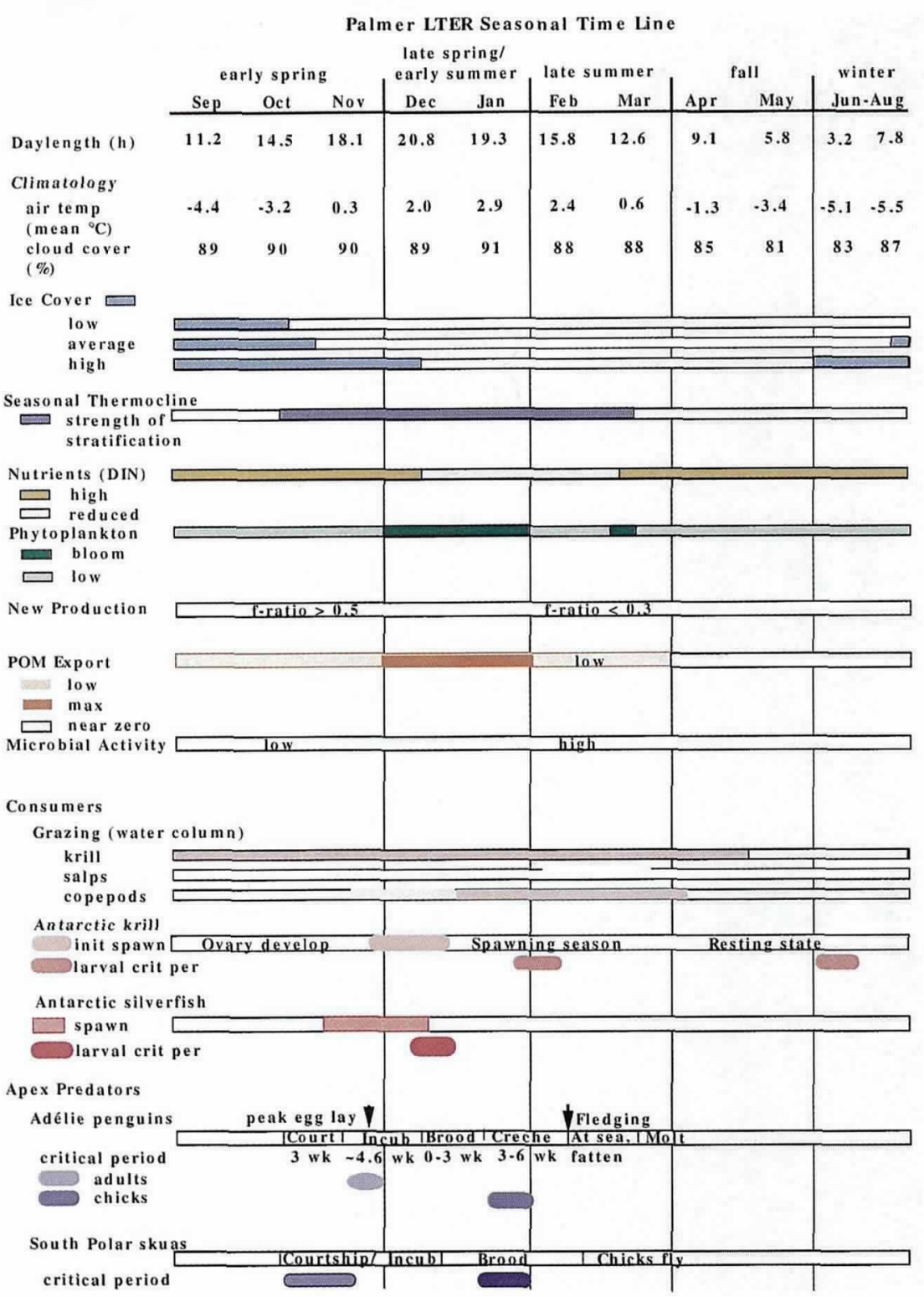

Fig. 4: Annual time-lines of key physical and biological components in the vicinity of Palmer Station (within $100 \mathrm{~km}$ ) based on generalized knowledge of Antarctic waters and preliminary findings from the Palmer LTER field seasons (see text). Timing associated with climatology, sea ice cover, and life histories of consumers and apex predators is relatively well known. Development of the seasonal thermocline and the corresponding strength and depth of stratification, nutrient history and phytoplankton development varies interannually with the timing, and strength of environmental forcings and are shown schematically to illustrate the potential temporal linkages.

ally bloom in late summer or fall if at all. Adult copepods migrate into surface layers in spring/summer, while the new year class appears in summer and intensifies grazing pressure. Grazing pressure then decreases in fall and winter as many copepods migrate into deeper layers.

Adélie penguins have a circumpolar distribution and a breeding season that passes through a series of stages in which their energetic requirements greatly vary. The season begins with a three week 
O

sampling

strategy combines

seasonal time series

data from the fine-

scale Palmer grid,

including the sea bird

nesting sites, with data

collected from re-

search cruises which

cover the large-scale

peninsula grid. courtship period, during which both members of the pair remain ashore fasting. This is followed by a month long incubation period from late November through December. The incubation duties begin with the male on the nest requiring him to fast for an additional two weeks, while the female goes to sea to feed. During this first critical period the female is believed to return to the ice edge in search of a predictable source of krill to restore her body condition (W. Trivelpiece, personal observation). If the female fails to replenish her supply of fat and return to the nest within two weeks, the male abandons the nest to forage and the eggs are lost. If the female is successful in finding food, she relieves her mate at the nest, and he spends the following two weeks at sea recovering from his five weeks of fasting. Upon the return of the male, the pair alternate between attending the eggs and foraging at sea on progressively shorter time intervals, until they are switching duties daily by the time the eggs (usually two) hatch. Following hatching, the pair continue alternating between guarding the chicks at the nest and foraging for food for their young until the chicks reach approximately three weeks of age. A second critical period affecting breeding success occurs in mid to late January, when the chicks are between three and seven weeks old. During this "creche stage," the food/energy demands of the chicks are at their highest. The parents must find predictable supplies of krill within a foraging area of about $100 \mathrm{~km}$, or preferably much closer, otherwise breeding success may be significantly reduced.

South polar skuas (Catharacta maccormicki), like Adélie penguins, have a circumpolar breeding distribution. In high latitude areas, south polar skuas typically breed near Adélie penguin breeding colonies, and indeed a significant portion of the south polar skua's diet consists of Adélie eggs and chicks. However, in the region of the Antarctic Peninsula, including the breeding sites near Palmer station, the south polar skua's range overlaps with that of its larger congener, the brown skua (Catharacta lonnbergi). Here, brown skuas control the penguin resource, forcing the smaller south polar skuas to feed exclusively at sea. Thus, in the area of the Palmer LTER, the south polar skua's breeding success is dependent on the distribution, availability, and abundance of food (krill, fish or scavenged penguin eggs and chicks) within its foraging range and the variable energy demands that are directly coupled to foraging. Pairs arrive at their nesting territories from mid-October to November, and males courtship-feed the females to bring them into reproductive condition. Annual variations in laying dates, number of eggs produced ( 1 or 2), and egg sizes all reflect the availability and abundance of food during this courtship period. The survival of south polar skua chicks also varies from year to year and appears to be specifically linked to the presence of silverfish in the chicks' diet. Years of low silverfish abundance are associated with total reproductive failure (Trivelpiece et al., 1990). High silverfish abundance, and thus reproductive success in skuas, have been correlated with years of lower than average ice cover.

\section{Sampling Strategies and Data Management}

Our sampling strategy combines seasonal time series data from the fine-scale Palmer grid, including the sea bird nesting sites, with data collected from research cruises which cover the large-scale peninsula grid. The relatively continuous weekly data obtained on the fine-scale grid from approximately October through March provide information on the seasonal progression of hydrography, nutrients, pigment biomass, primary productivity, and near-shore abundance and distribution of krill and their larvae, as well as yearly information on the timing and reproductive fate of the apex predators. These near-shore data also allow the largescale cruise data to be placed into a seasonal context to estimate interannual variability better. During the first four field seasons, there were six research cruises, each of which covered a significant portion of the large-scale peninsula grid during various times of the year (August/September, November, January, March/April) to address large scale seasonal variability. In addition, there have been a series of three January cruises chosen to coincide with the critical period of Adélie penguin chick growth and survival. These January cruises typically include 1) intensive sampling of all LTER components within the Adélie penguin foraging area and 2) large-scale sampling within the peninsula grid. The large-scale sampling resolves physical and biological variables which cannot be detected in the fine scale sampling and thus places the fine-scale observations in a more accurate environmental context, while the opposite is true for variables detected only in the fine scale sampling.

Data management and computer networking are key elements of all LTER sites. The LTER Network Office for intersite communications encourages electronic connectivity using the Internet (http://www.lternet.edu) to facilitate communications among distributed researchers (Andrews et al., 1992). In addition to the sharing of information and data within the LTER computer network, this approach has facilitated the sharing of computer resources and technology as well. Each site designates a data manager, who works with the other researchers to create on-line documentation and to manage and archive project data. Data management for the Palmer LTER is organized using a decentralized model, where each researcher is responsible for a subset of core and noncore data. For the Palmer LTER the documentation and data storage are organized through an electronic hub at the Institute for Computational Earth System Science (ICESS) at the 
University of California at Santa Barbara, which also serves as a data archive as needed (http://www.icess.ucsb.edu/lter). There are set definitions of core datasets and metadata, providing a common vocabulary and archive structure across the diverse LTER programs. The data archive structure has been organized to facilitate rapid information exchange and online data documentation.

\section{Summary}

The conceptual diagram of the ecosystem (Fig. 3 ) and the annual time-lines of key physical and biological components (Fig. 4) provide an initial construct for defining air-ocean-ice-ecosystem and trophic-level linkages. The interannual variability in sea ice coverage allows us to "conduct" natural experiments on the impact sea ice has on various trophic levels by monitoring parameters and processes during and after seasons/years of different sea ice coverage. Prior to the Palmer LTER, there were few systematic long-term, large-scale studies in Antarctica that would allow one to distinguish secular trends from cycles and to evaluate interannual variability inherent in the system. Palmer LTER research encompasses short and long temporal scales as well as fine and regional spatial scales and thus is poised to resolve ecosystem dynamics and linkages, in addition to providing a historical long-term data base for future ecosystem studies in this region.

A further motivation for this long-term approach is the recognition that the underlying natural variability in this marine ecosystem cannot be understood, evaluated nor distinguished from potential anthropogenic impacts in the Antarctic without long-term study. Some climate models place high latitude changes in sea ice cover as an indicator of global warming (Stouffer et al. 1989) and the seasonal ice zone as a region which may show a relatively large and early response to predicted greenhouse-gas warming. A statistically significant warming trend over the past 50 years has been shown for the mid-Antarctic Peninsula area (King, 1994; Stark, 1994; Smith et al., 1996a) and the significant correlations between air temperature, sea ice and the Southern Oscillation Index (Smith et al., 1996a; White and Peterson, personal communication) suggest that the Palmer LTER area may be uniquely well located to study ecological responses to climate variability.

Separating long-term (decadal) systematic trends from large interannual variability in populations is vital to measure the effects of increased human pressure on living resources and uphold the agreement of the Convention for the Conservation of Antarctic Marine Living Resources (CCAMLR). CCAMLR states that any living resource (e.g., krill) should not be harvested to such an extent that either the population itself or consumers depending on that food item are affected. With the continuation of the Palmer LTER we expect to understand the processes under- lying interannual variability, and thus be in a position to separate changes dependent on natural cycles from those due to long-term trends. Understanding natural variability within the Antarctic marine environment is fundamental to our understanding of the more subtle impacts of humankind.

\section{Acknowledgement}

The Palmer LTER is funded by the National Science Foundation Office of Polar Programs, Grant OPP90-11927 and DPP91-18439 (D.K.). Field sampling is done at Palmer Station and on board the R/V Polar Duke and R/V Nathaniel B. Palmer, under the administration of Antarctic Support Associates.

\section{References}

Ainley, D.G.. W.R. Fraser, C.W. Sullivan, J.J. Torres, T.L. Hopkins and W.O. Smith, 1986: Antarctic mesopelagic micronekton: evidence from seabirds that pack ice affects community structure. Science, 232, 847-849.

. C.A. Ribic and W.R. Fraser, 1994: Ecological structure among migrant and resident seabirds of the ScotiaWeddell confluence region. J. Anim. Ecol., 63, 347-364.

Amos, A.F., 1993: RACER: The tides at Palmer Station. Antarct. J. U. S., 28, 162-165.

Andrews, M., K. Baker, B. Benson. E. Boose. J. Brunt. C. Bledsoe, J. Briggs, G. Calabria. A. Elhaddi, D. Henshaw, R. Ingersoll, T. Kirchner. M. Klingensmith. L. Krievs, J. Laundre, R. Lent, E. Melendez, W. Michener, B. Nolen, R. Nottrott, J. Porter, S. Stafford, and C. Veen, 1992: Report of a Workshop, Proceedings of the 1992 LTER Data Management Workshop, R. Nottrott and R.J. Porter, eds., Long-Term Ecological Research Network Office, College of Forest Resources, AR-10. University of Washington. Seattle, WA, $45 \mathrm{pp}$.

Azam, F., T. Fenchel, J.G. Field, J.S. Gray, L.A. Meyer-Reil and F. Thingstad. 1983: The ecological role of water-column microbes in the sea. Mar. Ecol. Prog. Ser., 10, 257-263.

Baker, K.S. and S. Stammerjohn, 1995: Palmer LTER: Palmer Station weather records. Antarct. J. U. S., accepted 30(5).

Boyd, P.W., C. Robinson, G.J. Savidge and P.J. Williams, 1995: Water column and sea-ice primary production during Austral spring in the Bellingshausen Sea. DeepSea Res. Part II, 42, 1177-1200.

Brenneman, J., ed., 1989: Long-term ecological research in the United States, a network of research sites, Long-Term Ecological Research Network Office, University of Washington, Seattle, WA, 44 pp.

Bromwich, D.H. and C.R. Stearns, eds. 1993: Antarctic Meteorology and Climatology: Studies Based on Automatic Weather Stations, American Geophysical Union. New York, $207 \mathrm{pp}$.

Callahan. J.T., 1984: Long-Term Ecological Research. BioScience, 34, 363-367.

Chavez. F.P. and R.T. Barber, 1987: An estimate of new production in the equatorial pacific. Deep-Sea Res., 34, 1229-1243.

Christian, J.R. and D.M. Karl. 1994: Relative activities of several bacterial exoenzymes in the Western Antarctic Peninsula during Austral Summer: evidence of sea ice influence on pelagic bacterial communities. Antarct. $J$. U. S., $29(5), 212-214$.

Cota, G.F., S.T. Kottmeier, D.H. Robinson, W.O. Smith and C.W. Sullivan, 1990: Bacterioplankton in the marginal ice zone of the Weddell Sea: Biomass, production and metabolic activities during austral autumn. Deep-Sea Res. 37, 1145-1167.

El-Sayed, S.Z., ed., 1994: Southern Ocean ecology: the BIOMASS perspective, Cambridge University Press, New York, $339 \mathrm{pp}$. he interannual

variability in sea ice

coverage allows us to

"conduct" natural

experiments on the

impact sea ice has on

various trophic levels

by monitoring

parameters and

processes during and

after seasons/years of

different sea ice cover-

age. 
Franklin, J.F., C.S. Bledsoe and J.T. Callahan, 1990: Contributions of the long-term ecological research program. BioScience, 40, 509-523.

Fraser, W.R., W.Z. Trivelpiece, B.R. Houston and D.R. Patterson, 1992: Palmer LTER: Seabird research undertaken during 1991-1992 at Palmer Station, Antarctic peninsula. Antarct. J. U. S., 27, 249-250.

- and W. Trivelpiece, 1996: Factors controlling the distribution of seabirds: winter-summer heterogeneity in the distribution of Adelie penguin populations. In: Foundations for Ecological Research West of the Antarctic Peninsula, vol. 70. R.M. Ross, L.B. Quetin and E.E. Hofmann, eds., (AGU Antarctic Research Series).

Harris, C.M. and B. Stonehouse, eds., 1991: Antarctic and Global Climatic Change, London, Lewis Publishers, Belhaven Press, in association with the Scott Polar Research Institute, University of Cambridge, $198 \mathrm{pp}$.

Hedgpeth, J.W., 1977: The Antarctic Marine Ecosystem. In: Adaptations within Antarctic Ecosystems: Proceedings of the Third SCAR Symposium on Antarctic Biology. G.A. Llano, ed., Gulf Publishing, Houston. Sponsored by the Scientific Committee for Antarctic Research (SCAR) and the International Union of Biological Sciences and held under the auspices of the United States National Academy of Sciences. Washington, DC, 3-10.

Hofmann, E.E., J.M. Klinck, C.M. Lascara and D. Smith, 1996: Water mass distributions and circulation west of the Antarctic Peninsula and including Bransfield Strait. In: Foundations for Ecological Research West of the Antarctic Peninsula, vol. 70. R.M. Ross, L.B. Quetin and E.E. Hofmann, eds., (AGU Antarctic Research Series).

Holm-Hansen, O., B.G. Mitchell, C.D. Hewes and D.M. Karl, 1989: Phytoplankton blooms in the vicinity of Palmer Station, Antarctica. Polar Biology, 10, 49-57.

Hunt, G.L., 1991: Marine birds and ice-influenced environments of polar oceans. J. of Marine Systems, 2, 233-240.

Johannessen, O.M., R.D. Muench and J.E. Overland, eds., 1994: The Polar Oceans and Their Role in Shaping the Global Environment: the Nansen Centennial volume, Geophysical Monograph, 85, American Geophysical Union, Washington, DC, $525 \mathrm{pp}$.

Karl, D.M., 1991: RACER-Research on Antarctic coastal ecosystem rates-preface, Part A-Oceanographic Research Papers. Deep-Sea Res., 38, R5-R7,

, O. Holm-Hansen, G.T. Taylor, G. Tien and D.F. Bird, 1991: Microbial biomass and productivity in the western Bransfield Strait, Antarctica during the 1986-87 austral summer. Deep-Sea Res., 38, 1029-1055.

and D.F. Bird, 1993: Bacterial-algal interactions in antarctic coastal ecosystems, Sixth International Symposium on Microbial Ecology. In: Trends in Microbial Ecology, R. Guerrero and C. Pedros-Alio, eds., Spanish Society for Microbiology, 37-40.

King, J.C., 1994: Recent climate variability in the vicinity of the Antarctic Peninsula. Inter. J. of Climatology, 14, 357-369.

Kocmur, S.F.. M. Vernet and O. Holm-Hansen, 1990: RACER: Nutrient depletion by phytoplankton during the 1989 austral spring bloom. Antarct. J. U. S., 25, 138-141.

Lancelot, C., S. Mathot, C. Veth and H.W. de Baar, 1993: Factors controlling phytoplankton ice-edge blooms in the marginal ice-zone of the Northwestern Weddell Sea during sea ice retreat 1988-Field observations and mathematical modelling. Polar Biology, 13, 377-387.

Palmisano, A.C. and D.L. Garrison, 1993: Microorganisms in Antarctic sea ice. In: Antarctic Microbiology, E.I. Friedmann, ed., Wiley-Liss, Inc., New York, 167-218.

Petit, J.R., J.W.C. White, N.W. Young, J. Jouzel and Y.S. Korotkevich, 1991: Deuterium excess in recent Antarctic snow. J. Geophys. Res., 96, 5113-5122.
Quetin, L.B., R.M. Ross and A. Clarke, 1994: Krill energetics: seasonal and environmental aspects of the physiology of Euphausia superba. In: Southern Ocean ecology: the BIOMASS perspective, S.Z. El-Sayed, ed., Cambridge University Press, pp. 165-184.

Ross, R.M. and L.B. Quetin, 1991: Ecological physiology of larval euphausiids, Euphausia superba (Euphausiacea). Memoirs of the Queensland Museum, 31, 321-333.

Siegel, V. and V. Loeb, 1995: Recruitment of Antarctic krill euphausia superba and possible causes for its variability. Mar. Ecol. Prog. Ser., 123, 45-56.

Smith, W.O. and D.M. Nelson, 1985: Phytoplankton biomass near a receding ice-edge in the Ross sea. In: Antarctic Nutrient Cycles and Food Webs, W.R. Siegfried, P.R. Condy and R.M. Laws, eds., Springer-Verlag, Berlin, 70-77.

Smith, R.C., B.B. Prezelin, K.S. Baker, R.R. Bidigare, N.P. Boucher, T. Coley, D. Karentz, S. Maclntyre, H.A. Matlick, D. Menzies, M. Ondrusek, Z. Wan, and K.J. Waters, 1992: Ozone depletion: Ultraviolet radiation and phytoplankton biology in Antarctic waters. Science, 255, 952-959.

, S.E. Stammerjohn and K.S. Baker, 1996a: Surface air temperature variations in the Western Antarctic Peninsula region. In: Foundations for Ecological Research West of the Antarctic Peninsula. vol. 70. R.M. Ross, L.B. Quetin and E.E. Hofmann, eds., ( $A G U$ Antarctic Research Series).

, H. Dierssen and M. Vernet, 1996b: Phytoplankton biomass and productivity in the Western Antarctic Peninsula region. In: Foundations for Ecological Research West of the Antarctic Peninsula, vol. 70. R.M. Ross, L.B. Quetin and E.E. Hofmann, eds., ( $A G U$ Antarctic Research Series).

Stammerjohn, S.E., 1993: Spatial and temporal variability in Southern Ocean sea ice coverage, University of California, Santa Barbara, CA. 111 pp.

, and R.C. Smith, 1996: Spatial and temporal variability of Western Antarctic Peninsula sea ice coverage. In: Foundations for Ecological Research West of the Antarctic Peninsula, vol. 70. R.M. Ross, L.B. Quetin and E.E. Hofmann, eds., (AGU Antarctic Research Series).

Stark, P., 1994: Climatic warming in the central Antarctic Peninsula area. Weather, 49, 215-220.

Stein, M., 1992: Variability of local upwelling off the Peninsula, 1986-1990. Archiv fur Fischereiwissenschaft, 41, 131-158.

Stouffer, R.J., S. Manabe and K. Bryan. 1989: Interhemispheric asymmetry in climate response to a gradual increase of atmospheric $\mathrm{CO}_{2}$. Nature, 342, 660-662.

Strayer, D., J.S. Glitzenstein, C.G. Jones, J. Kolasa, G.E. Likens, M.J. McDonnell, G.G. Parker and L.S.T.A. Pickett, 1986: Long-Term ecological studies: an illustrated account of their design, operation, and importance to ecology, Occasional Publication of The Institute of Ecosystem Studies, pp. 1-38.

Treguer, P. and G. Jacques, 1992: Dynamics of nutrients and phytoplankton, and fluxes of carbon. nitrogen and silicon in the Antarctic Ocean. Polar Biology, 12, 149162.

Trivelpiece. W.Z., D.G. Ainley, W.R. Fraser and S.G. Trivelpiece, 1990: Skua survival. Nature, 345, 211-211.

Turner, D. and N. Owens, 1995: A biogeochemical study in the Bellingshausen Sea: Overview of the STERNA 1992 expedition. In: Deep-Sea Res. Part II, J.D. Milliman, D. Turner, N. Owens, and J. Priddle, eds., Pergamon, Great Britain, 907-932.

Waters, K.J. and R.C. Smith, 1992: Palmer LTER: A sampling grid for the Palmer LTER program. Antarct. J. U. S., 27, 236-239. $\square$ 